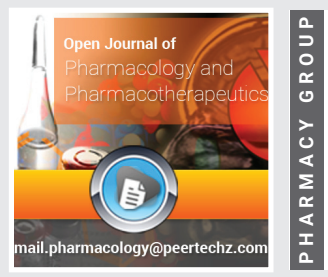

\section{Antibacterial, antioxidant and antihypertensive properties of polyphenols from argentinean red wines varieties}

\author{
María J Rodríguez-Vaquero ${ }^{1 *}$, Claudia V Vallejo and Pedro \\ A Aredes-Fernández ${ }^{2}$
}

${ }^{1}$ Institute of Microbiology, Faculty of Biochemistry, Chemistry and Pharmacy (FBQF), National University of Tucumán (UNT) and CONICET, Ayacucho 471, 4000, Tucumán, Argentina

${ }^{2}$ Institute of Biotechnology, FBQF-UNT-CONICET, Argentina
Received: 18 February, 2020

Accepted: 25 March, 2020

Published: 26 March, 2020

*Corresponding author: María J. Rodríguez-Vaquero, Institute of Microbiology, Faculty of Biochemistry, Chemistry and Pharmacy (FBQF), National University of Tucumán (UNT) and CONICET, Ayacucho 471, 4000, Tucumán, Argentina, Tel: +54 381 4247752; Ext: 7067; E-mail:mariajo@fbqf.unt.edu.ar

Keywords: Wine polyphenols; Antibacterial activity; Antioxidant activity; Antihypertensive activity

https://www.peertechz.com

Check for updates

\begin{abstract}
The aims of this study were to determine the phenolic profile of three Argentinean wine varieties and their antioxidant, antihypertensive and antibacterial activities. Gallic acid, quercetin and rutin were the principal phenolic compounds identified in wines. All wines possess a high antihypertensive and antioxidant activities. Among 3 wines, merlot and malbec possess the higher ferric reducing power and DPPH and ABTS radical scavenging activity. Lower ferric reduced power and radical scavenging values were found in clarified wines. High correlation coefficients were found between phenolic content and antioxidant and antihypertensive capacities, confirming that phenolic compounds are likely the responsible for these activities in wines. The inhibition of biofilm formation and MIC and MBC values of wines polyphenols against $E$. coli, Pseudomonas aeruginosa, Staphylococcus aureus and L. monocytogenes was demonstrated. The higher antibacterial, antioxidant and ACEI activities of merlot and malbec wines compared with cabernet sauvignon could be related to the higher concentration of individual phenolic compounds, such as quercetin, rutin, kaempferol, caffeic acid and gallic acids in malbec and merlot wines.
\end{abstract}

\section{Introduction}

Vitis vinifera $\mathrm{L}$. is one of the most cultivated crops in the world; most of the production is directed towards wine production. Wine is a complex mixture of several hundred compounds present at different concentrations, some originating from the grapes and some metabolic by-products of yeast activity during fermentation [1]. Red wine is a rich source of polyphenols and the phenolic composition of wine is determined initially by the phenolic composition of the grapes used for making the wine, temperature, or exposure to sunlight. Moderate consumption of red wine has been associated with several health benefits, including cardioprotective, antiinflammatory and antibacterial properties [2-4], related mainly with phenolic compounds activities. Moreover, phenolic compounds present in some fruits, herbs and beverages are known to be free radicals inhibitors [5] and are capable to inhibit Angiotensin I-converting enzyme (ACE) [6]. Free radicals and other reactive oxygen species are recognized as agents involved in the pathogenesis of several sicknesses such as Parkinson's and Alzheimer's diseases, so antioxidant plays an important role in inhibiting and scavenging free radicals, providing protection to human against degenerative diseases. On other way, ACE plays an important physiological role in the regulation of blood pressure and cardiovascular function [7]. ACE catalyzes the hydrolysis of angiotensin I, an inactive decapeptide, to angiotensin II, a powerful vasoconstrictor and salt-retaining octapeptide. Therefore, ACEinhibitor compounds exert an antihypertensive action [8].

On the other hand, phenolic compounds may affect growth and metabolism of bacteria, they could have an activating or inhibiting effect on bacterial growth according to their constitution and concentration [4,9]. Pseudomonas aeruginosa, Escherichia coli and Staphylococcus aureus bacteria are registered as the main cause of diseases that affect and kill people all 
over the world. P. aeruginosa is one of the major agents causing hospital infections, being responsible for most respiratory and urinary tract infections. Most E. coli strains harmlessly inhabit the colon, a large number of pathogenic strains may cause intestinal diseases such as diarrhea $[10,11]$. S. aureus is considered an opportunistic pathogen, being responsible for numerous acute infections, such as pneumonia, osteomyelitis, endocarditis, myocarditis, pericarditis and meningitis [12]. Bacterial resistance is growing day to day, so the discovered of new antibacterial agents is required, in this sense some authors demonstrated the antibacterial activities of pure phenolic compounds [4] and aqueous and ethanolic extracts against several pathogenic bacteria [13].

Argentine is the fifth wine producer in the world $[14,15]$. The hypothesis of this work that polyphenols combinations presents in Argentinean wines possess antioxidant, antihypertensive and antibacterial activities against pathogenic bacteria, which is related with the phenolic composition of the grape variety.

The aims of this work were to investigate the antioxidant, antihypertensive and antibacterial activities of polyphenols from red wines made with different grape varieties (malbec, merlot and cabernet sauvignon) produced in Argentine vineyards. The phenolic profile, the difference between wine varietals and the correlation between total phenolic compound content and these activities were determined.

\section{Materials and methods}

\section{Characterization of phenolic compounds in wines}

Red wines samples, made with cabernet sauvignon, malbec and merlot grape varietals, were obtained from different cellars situated in Mendoza, Argentina (vintages 2012). Colorimetric determination of total phenolic compounds was based on the procedure of Singleton and Rossi [16] and results are expressed as milligram per liter Gallic Acid Equivalents (GAE). Phenolic characterization was carried out according to Ghiselli et al. [17] and the profile of the low phenolic molecular weight fraction of all wines was identified and quantified by HPLC analysis. The equipment was coupled to a diode array detector according to the technique described by Fanzone, et al. [18].

\section{Antihypertensive activity}

The angiotensin I-Converting Enzyme Inhibitory (ACEI) activity of wines and theirs clarified wines was determined using the method described by Cushman and Cheung [19] and later modified by Hernández-Ledesma, et al. [20]. In order to eliminate all phenolic compounds from the wines (controls), they were clarified by the addition of $30 \mathrm{mg} / \mathrm{l}$ of activated charcoal. ACEI activity is expressed as follows:

$\%$ of ACEI $=100[(A-B)-(C-D)] /(A-B)$

where A represents the absorbance in the presence of ACE, $\mathrm{B}$ the absorbance of the reaction blank, $\mathrm{C}$ the absorbance in the presence of ACE and inhibitor and D absorbance of the sample blank.

\section{Antioxidant activity}

The antioxidant capacity of wines and theirs clarified wines was determined using three methods, the FerricReducing Antioxidant Power assay (FRAP) assay, free DPPH (1,1-diphenyl-2-picrilhydrazyl) radical scavenging activity and free ABTS (2,2'-azino-bis(3-ethylbenzothiazoline-6sulphonic acid) radical scavenging activity.

FRAP assay was carried out according to the procedure of Benzie and Strain [21]. The results were expressed as $\mu \mathrm{mol} / \mathrm{l}$ $\mathrm{FeSO}_{4}$. The free radical scavenging activity was determined using a stable ABTS radical as described Re et al. [22], and using a stable DPPH radical and following the method proposed by Von Gadow et al. [23]. The percentage inhibition of the DPPH radical by the samples was calculated according to the formula of Yen and Duh [24]:

$\%$ inhibition $=\left[\left(A_{C(o)}-A_{A(t)}\right) / A_{C(o)}\right] \times 100(2)$

Where,

$\mathrm{A}_{\mathrm{C}(\mathrm{o})}$ is the absorbance of the control at $\mathrm{t}=0 \mathrm{~min}$,

$A_{A(t)}$ is the absorbance of the antioxidant at $t=15 \mathrm{~min}$.

\section{Antibacterial activity of polyphenols from wines}

\section{Bacterial Strains and Culture Conditions.}

The bacterial strains used as test organism were Escherichia coli ATCC35218, Escherichia coli.

ATCC 25922, Staphylococcus aureus ATCC 25923, Staphylococcus aureus ATCC 29213 and Pseudomonas aeruginosa ATCC 27853. Escherichia coli and Listeria monocytogenes, isolated from human infection and obtained from the culture collection of FBQFUNT were also studied. All bacteria were cultured aerobically at $37^{\circ} \mathrm{C}$ in nutrient broth and agar medium (contain in $\mathrm{g} / \mathrm{l}$ : beef extract, 3; peptone, 5; sodium chloride, 8 and for solid medium, agar 15). Before experimental use, cultures from solid medium were sub-cultivated in liquid media, incubated for $24 \mathrm{~h}$ and used as the source of inoculums for each experiment.

Minimum Inhibitory Concentrations (MIC) and Minimum Bactericide Concentrations (MBC).

MIC and MBC of merlot, malbec and cabernet sauvignon wine varieties and theirs clarified wines against selected bacteria were determined in Mueller-Hinton broth, using the macro broth dilution method as described by the Clinical \& Laboratory Standards Institute [25]. The final concentration of bacteria in each macro broth dilution tube was approximately $5 \times 10^{5} \mathrm{cfu} / \mathrm{ml}$ of MHB. The MIC and CBM values were compared with those obtained with the addition of clarified wines, and the difference of both were the final values. The positive control used was chloramphenicol $(1 \mathrm{mg} / \mathrm{ml})$.

\section{Influence of Polyphenols on Bacterial Biofilm Formation.}

The efficiency of polyphenols from wines to inhibit biofilm formation of selected bacteria was carried out. In brief, $10^{6}-10^{7}$ 
$\mathrm{cfu} / \mathrm{ml}$ bacterial culture was filled in the wells of 96-well-flat bottom plate. $50 \mu \mathrm{l}$ of wines or clarified wines samples were added in corresponding wells of the plate and incubated at 20

${ }^{\circ} \mathrm{C}$ for $24 \mathrm{~h}$. To remove planktonic bacteria, the wells were washed twice with phosphate buffer saline (PBS, pH 7.4) and finally, crystal violet (CV $0.1 \%, \mathrm{w} / \mathrm{v}$ ) was used to stain the cells in biofilm for $1 \mathrm{~h}$. The wells were washed with PBS and the stained biofilms were extracted with $200 \mu \mathrm{L}$ of $96 \%$ ethanol. The amount of biofilm was quantified by measuring the OD $595 \mathrm{~nm}$ of dissolved CV using the microplate reader. A control of biofilm formation of each bacterium was made without the addition of wines or clarified wines. The inhibition of biofilm formation was calculated by using the formula:

$\%$ Biofilm inhibition $=\left[\left(O D_{\text {control }}-O D_{\text {test }}\right) / O D_{\text {control }}\right] \times 100$

where OD control is the absorbance without the addition of wines or clarified wines.

\section{Statistical analysis}

The means and reproducibility of data were calculated based on three independent experiments

performed in triplicate. Statistical analysis was carried out according to Steel, et al. [26]. Experimental data of bacterial viability were analyzed using the one-way analysis of variance test.

\section{Results}

The phenolic compound profiles present in different wine varieties are shown in Table 1 . Quercetin, rutin, catechin and gallic acid were the principal phenolic compounds identified in wines, but their concentration in malbec and merlot wine varietals are higher than in cabernet sauvignon wine.

The total phenolic content, ACEI and antioxidant activities of wines and clarified wines were showed in Table 2. There was not significantly difference between the total phenolic content of malbec and merlot, which are higher than in cabernet sauvignon wine.

All wines possess antihypertensive and antioxidant activities. Among 3 wines varieties, merlot and malbec possess higher antioxidant activity than cabernet sauvignon variety, determinate by three different methods. Clarified wines of three varieties showed to possess the lowest ferric reduced power and radical scavenging activity. To correlate the phenolic compounds concentrations with the antioxidant capacities, the correlation coefficients $\left(R^{2}\right)$ were calculated (Figure 1 ). The $R^{2}$ between radical scavenging activities, FRAP and from ACEI activity and polyphenol concentrations were around 0.99 in all cases. So, those results confirming that phenolic compounds are likely the responsible for the antioxidant and antihypertensive activities in wines.

The MIC and MBC values of the three wine varieties and their clarified wines against studied bacteria are presented in Table 3. The CIM and CBM values for clarified wines were higher than $1000 \mathrm{mg} / \mathrm{l}$. The three strains of E. coli and L. monocytognes were
Table 1: Profile of phenolic compounds $(\mu \mathrm{g} / \mathrm{ml})$ in Argentinean red wines. malbec $(n=20)$ merlot $(n=18)$ cabernet sauvignon $(n=18)$

\begin{tabular}{|c|c|c|c|}
\hline & malbec $(n=20)$ & merlot $(n=18)$ & cabernet sauvignon $(n=18)$ \\
\hline Gallic acid & $20.0 \pm 2.3^{\mathrm{a}}$ & $21.5 \pm 2.8^{\mathrm{a}}$ & $15.0 \pm 2.0^{\mathrm{b}}$ \\
\hline $\begin{array}{c}\text { Protocatechuic } \\
\text { acid }\end{array}$ & $4.0 \pm 0.3^{\mathrm{a}}$ & $3.5 \pm 0.2^{\mathrm{b}}$ & $2.0 \pm 0.2^{\mathrm{c}}$ \\
\hline Methyl gallate & $1.6 \pm 0.1^{\mathrm{a}}$ & $15.0 \pm 3.0^{\mathrm{b}}$ & $2.5 \pm 0.3^{\mathrm{c}}$ \\
\hline Caffeic acid & $7.5 \pm 0.4^{\mathrm{a}}$ & $10.0 \pm 0.7^{\mathrm{b}}$ & $3.0 \pm 0.3^{\mathrm{c}}$ \\
\hline Ferulic acid & $1.6 \pm 0.2^{\mathrm{a}}$ & $5.1 \pm 0.4^{\mathrm{b}}$ & $1.2 \pm 0.2^{\mathrm{c}}$ \\
\hline Caftaric acid & $1.2 \pm 0.2^{\mathrm{a}}$ & $1.0 \pm 0.1^{\mathrm{a}}$ & $1.8 \pm 0.2^{\mathrm{b}}$ \\
\hline Myricetin & $N d$ & $1.2 \pm 0.1^{\mathrm{a}}$ & $6.2 \pm 0.6^{\mathrm{b}}$ \\
\hline Quercetin & $22.0 \pm 2.2^{\mathrm{a}}$ & $26.0 \pm 3.0^{\mathrm{b}}$ & $16.0 \pm 3.1^{\mathrm{c}}$ \\
\hline Rutin & $20.0 \pm 3.1^{\mathrm{a}}$ & $23.0 \pm 3.1^{\mathrm{a}}$ & $12.5 \pm 3.1^{\mathrm{b}}$ \\
\hline Catechin & $19.0 \pm 2.6^{\mathrm{a}}$ & $17.0 \pm 2.8^{\mathrm{a}}$ & $12.0 \pm 3.1^{\mathrm{b}}$ \\
\hline Kaempferol & $2.5 \pm 0.4^{\mathrm{a}}$ & $5.0 \pm 0.5^{\mathrm{b}}$ & $1.5 \pm 0.3^{\mathrm{c}}$ \\
\hline
\end{tabular}

$\mathrm{Nd}$ : Not detectedAll values represent the means of three determinations. Different letters in the same row show significant differences $(p<0.05)$.

Table 2: Antioxidant and antihypertensive activities of wine polyphenols.

\begin{tabular}{|c|c|c|c|c|c|}
\hline & \multicolumn{4}{|c|}{ Antioxidant activity } & $\begin{array}{c}\text { Antihypertensive } \\
\text { activity }\end{array}$ \\
\hline & $\begin{array}{c}\text { Total } \\
\text { Phenolic } \\
\text { compounds* }\end{array}$ & $\begin{array}{c}\text { FRAP } \\
(\mu \mathrm{mol} / / \\
\text { FeSO }_{4)}\end{array}$ & DPPH (\%) & ABTS (\%) & ACEI (\%) \\
\hline Wines: & & & & & \\
\hline merlot & $2,805 \pm 95^{\mathrm{a}}$ & $2,490 \pm 160^{\mathrm{a}}$ & $79 \pm 6.8^{\mathrm{a}}$ & $85 \pm 7.2^{\mathrm{a}}$ & $75 \pm 7.0^{\mathrm{a}}$ \\
\hline malbec & $2,650 \pm 80^{\mathrm{a}}$ & $2,380 \pm 170^{\mathrm{a}}$ & $77 \pm 5.0^{\mathrm{a}}$ & $81 \pm 5.5^{\mathrm{a}}$ & $64 \pm 6.2^{\mathrm{ab}}$ \\
\hline $\begin{array}{c}\text { c. sauvignon } \\
\text { Clarified wines }\end{array}$ & $2,400 \pm 80^{\mathrm{b}}$ & $2,010 \pm 135^{\mathrm{b}}$ & $67 \pm 4.0^{\mathrm{b}}$ & $70 \pm 5.0^{\mathrm{b}}$ & $60 \pm 5.0^{\mathrm{b}}$ \\
\hline merlot & $20.9 \pm 1.0^{\mathrm{a}}$ & $49.0 \pm 2.3^{\mathrm{a}}$ & $9.0 \pm 0.5^{\mathrm{a}}$ & $10.0 \pm 0.5^{\mathrm{a}}$ & $5.0 \pm 0.4^{\mathrm{a}}$ \\
\hline malbec & $23.0 \pm 1.3^{\mathrm{a}}$ & $53.0 \pm 2.5^{\mathrm{a}}$ & $10.0 \pm 0.5^{\mathrm{a}}$ & $11.0 \pm 0.5^{\mathrm{a}}$ & $4.0 \pm 0.4^{\mathrm{a}}$ \\
\hline c. sauvignon & $20.6 \pm 1.1^{\mathrm{a}}$ & $48.0 \pm 2.5^{\mathrm{a}}$ & $10.0 \pm 0.5^{\mathrm{a}}$ & $10.0 \pm 0.5^{\mathrm{a}}$ & $7.0 \pm 0.4^{\mathrm{a}}$ \\
\hline
\end{tabular}

*mg/l GAE. Mean values with different superscript letters within the same column are significantly different according to the Turkey test $(\rho \leq 0.05)$.

the most sensitive to polyphenols from three wines, whereas St. aureus or P. aeruginosa were most resistant (Figure 2).

Regarding to the inhibition of bacterial biofilm formation, there were not differences between malbec and merlot wine varieties, and it was higher than that observed with the addition of cabernet sauvignon wine (Figure 3). The biofilm inhibition on E. coli and L. monocytogenes was higher than that observed against Staphylococcus aureus or Pseudomonas aeruginosa. All clarified wines showed a biofilm inhibition lower than $10 \%$, so, these results indicating that antibacterial activity of wines are related with phenolic compounds presents in wines, and Argentinean wines possess a strong antibacterial activity.

\section{Discussion}

The phenolic compound profiles and the antihypertensive, antibacterial and antioxidant activities of three Argentinean red wines varietals was reported in this work. And the relationship between these biological activities and the phenolic compounds content in each wine was demonstrated.

The total phenolic compounds concentrations in Merlot and Malbec wine varieties were higher than in Cabernet Sauvignon 

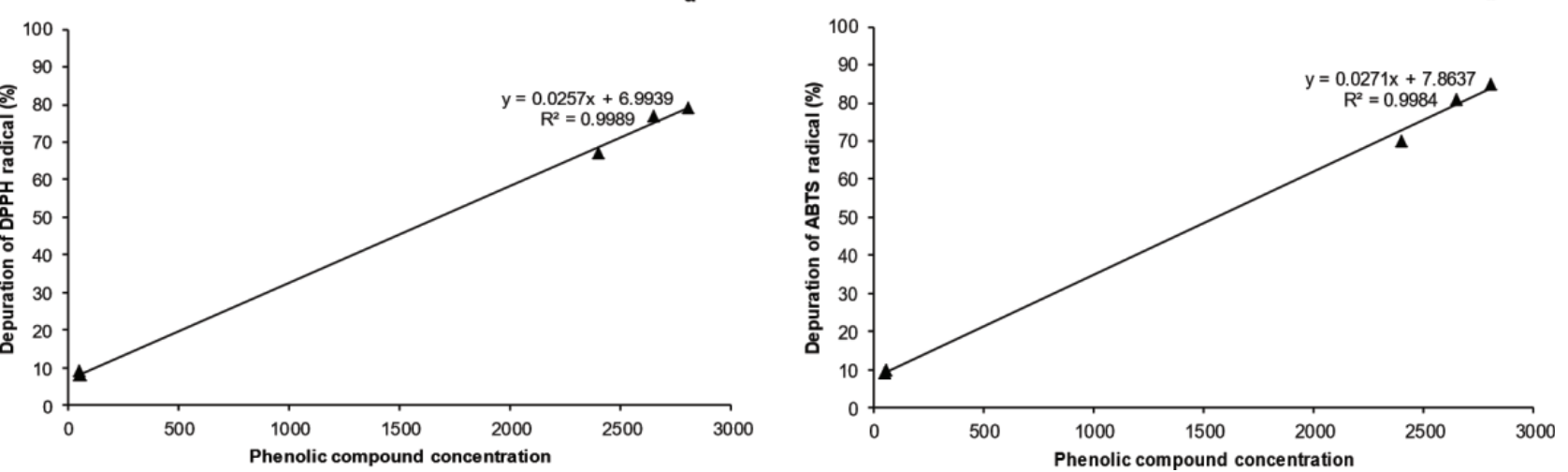

(mg GAE/l) ( $\quad$ g GAE/l)

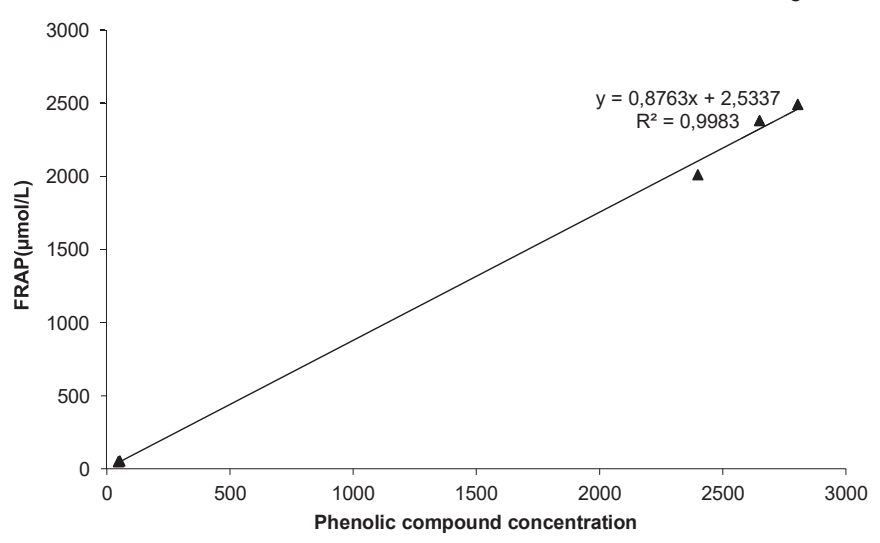

( $m g$ GAE/l)

Figure 1: Linear correlation between total phenolic compound concentration in wines and their 323 antioxidant capacities determine by DPPH (a), ABTS (b) and FRAP (c) assays.

Table 3: MIC and MBC values of polyphenols from wines against seven bacteria $(\mu \mathrm{g}$ of polyphenols $/ \mathrm{ml}$ ).

\begin{tabular}{|c|c|c|c|c|c|c|}
\hline & \multicolumn{5}{|c|}{ Polyphenols from Wines } \\
\hline & MIC & MBC & MIC & MBC & MIC & MBC \\
\hline Escherichia coli ATCC 35218 & 100 & 180 & 100 & 200 & 180 & 250 \\
\hline Escherichia coli ATCC 25922 & 150 & 200 & 150 & 200 & 150 & 250 \\
\hline Escherichia coli (human origin) & 150 & 250 & 180 & 300 & 200 & 300 \\
\hline Pseudomonas aeruginosa ATCC 27853 & 400 & 750 & 450 & 900 & 500 & 900 \\
\hline Staphylococcus aureus ATCC 29213 & 400 & 800 & 400 & 900 & 600 & $>1,000$ \\
\hline Staphylococcus aureus ATCC 25923 & 500 & 900 & 450 & 950 & 600 & $>1,000$ \\
\hline Listeria monocytogenes (human origin) & 120 & 250 & 150 & 250 & 200 & 300 \\
\hline
\end{tabular}

variety; and Merlot and Malbec wines samples were more effective as antioxidant, antibacterial and antihypertensive agents than Cabernet Sauvignon varietal. Besides, Merlot and Malbec wines content higher concentrations of gallic acid quercetin, rutin and catechin than Cabernet Sauvignon wines.

All wines samples possess antibacterial effect against E. coli, S. aureus, P. aeruginosa and L. monocytogenes, the controls carried out with clarified wines were inactive against all bacteria tested, indicating that the responsible of the antibacterial effect were the polyphenolic compounds present in red wine. Our results demonstrated that $S$. aureus and $P$. aeruginosa were more resistant to polyphenols from wines than $E$. coli and $L$. monocytogenes. In this sense, Bouarab-Chibane, et al. [27] determine the antimicrobial effect of 35 polyphenols belonging to different classes (cinnamic or benzoic acids, flavonoids, stilbenes, coumarins, naphtoquinones) against six foodborne pathogenic bacterial strains, three

Gram-positive (S. aureus, B. subtilis and L. monocytogenes), and three Gram-negative (E. coli, $P$. aeruginosa and $S$. enteritidis). The authors determined that polyphenols exhibited very different antibacterial activity against the six microbial strains studied, the same polyphenol may be effective on one type of Gram-positive (or Gram-negative) strain and ineffective on the other ones indicating straindependent effect and generally, L. monocytogenes was sensitive to polyphenols whereas $P$. aeruginosa was not. Other authors demonstrated the antibacterial activity of natural compounds presents in essential oil of Dysphania ambrosioides against Staphylococcus aureus $(256 \mu \mathrm{g} / \mathrm{mL})$ and Pseudomonas aeruginosa $(512 \mu \mathrm{g} / \mathrm{mL})$ [28]. 


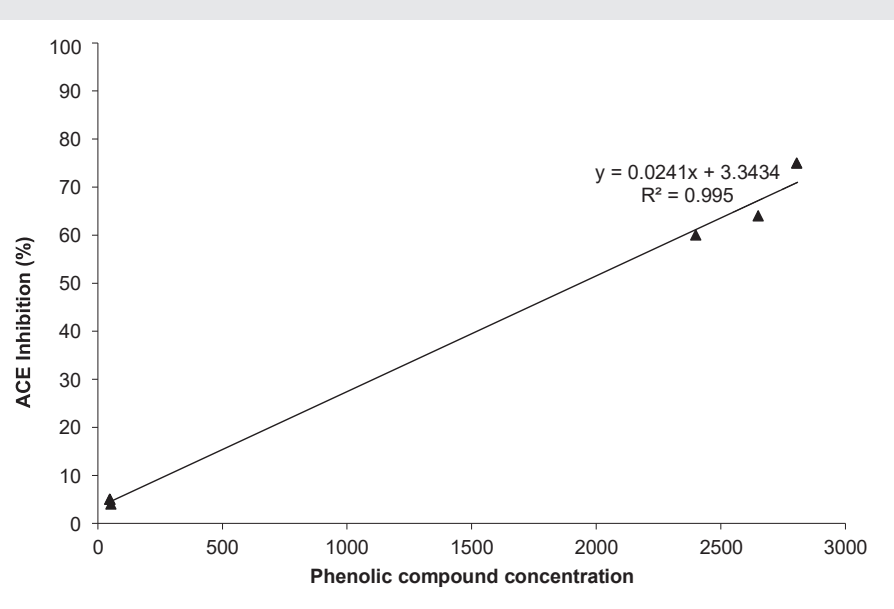

( $m g$ GAE/l)

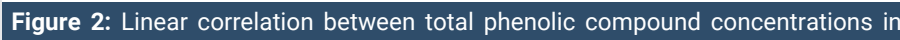
wines and their 325 antihypertensive activity.

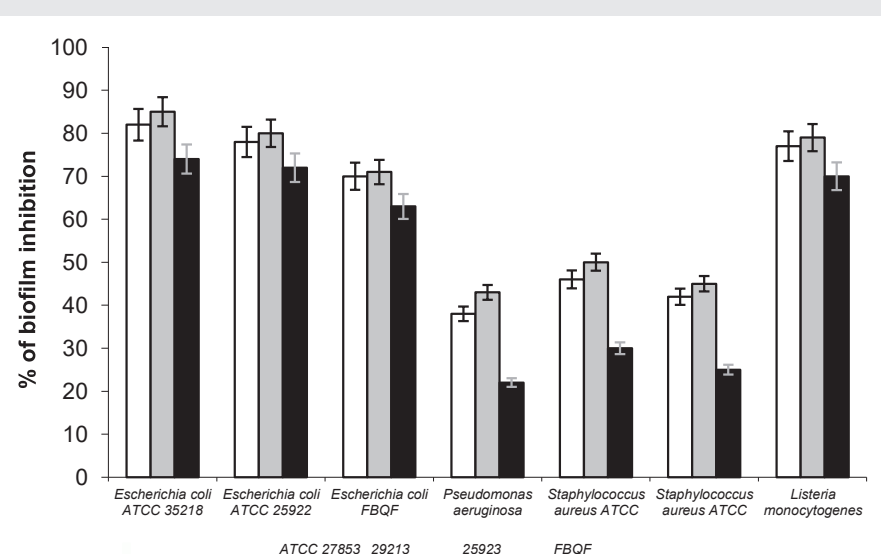

Figure 3: Effect of polyphenols from malbec ( $($ ) , merlot $(\square)$ and cabernet savignon ( ) wine varieties in biofilm inhibition. Biofilm inhibition was assessed by crystal violet staining and the results are expressed as percentage biofilm inhibition. Values are represented as mean \pm SD.

In this work the high correlation between the phenolic compounds concentrations and the antioxidant and antihypertensive capacities of wines was demonstrated. Our results are in agreement with those reported by FernandezPachon et al. [29], who reported that antioxidant activity of red wines is higher than that of white or sherry wines and that total phenolic content is related to antioxidant activity of wines. Van Leeuw et al. [30-32] demonstrated the antioxidant capacity of 38 wine varieties and the influence of the phenolic content, but reported exceptions were the wines produced from the grape variety Pinot Noir, in which the range of phenolic compounds was different from the other wines and this was associated with a lower antioxidant capacity. And Fidelis et al. [31], reported the relation of phenolic composition of camucamu seed coat and their antioxidant activity and ACEI in vitro.

The higher antibacterial, antioxidant and ACEI effects of merlot and malbec wines compared with cabernet sauvignon could be related to the higher concentration of total phenolic compounds in malbec and merlot wines. Moreover, this effect could be due to the higher concentration of individual phenolic compounds, such as quercetin, rutin, kaempferol, caffeic acid and gallic acids in malbec and merlot wines varieties than cabernet savignon wine. In previous work, Rodríguez-Vaquero et al. [4] reported that flavonol compounds such as rutin and quercetin, and phenolic acids, such as gallic and caffeic acids showed the highest antibacterial activity in culture medium against several bacteria. And Vallejo et al. [6] demonstrated that individual phenolic compounds, such as rutin and caffeic, ferullic and gallic acids produce a higher ACEI than others phenolic compounds.

\section{Conclusion}

The present study demonstrated the antihypertensive and antioxidant activities of polyphenols present in three Argentinean red wines varietals and their relation with the phenolic content, as well as their antibacterial activity against Escherichia coli, Staphylococcus aureus, Pseudomonas aeruginosa and Listeria monocytogenes. So, Argentinean wines are not only exquisite drinks in flavor for consumption, but are also healthy drinks taken in moderation of a cup per day.

\section{Acknowledgments}

The present study was supported by grants from CIUNTArgentina, Consejo Nacional de Investigaciones Científicas y Técnicas (CONICET) and Agencia Nacional de promoción científica y tecnológica (PICT 20151508 Préstamo BID).

\section{References}

1. Soleas GJ, Diamandis EP, Goldberg DM (1997) Wine is a biological fluid: history, production and role in disease prevention. J Clin Lab Anal 11: 287-313. Link: https://bit.ly/33KeoCW

2. Xia EQ, Deng GF, Guo YJ, Li HB (2010) Biological activities of polyphenols from grapes. International Journal of Molecular Sciences 11: 622-646. Link: https://bit.ly/33KeCdg

3. Artero A, Artero A, Tarín JJ, Cano A (2015) The impact of moderate wine consumption on health. Maturitas 80: 3-13. Link: https://bit.ly/2wCvfvr

4. Rodríguez-Vaquero MJ, Alberto MR, Manca de Nadra MC (2007) Antibacteria effect of phenolic compounds from different wines. Food Control 18: 93-101. Link: https://bit.ly/2wFgl1X

5. Rodríguez Vaquero MJ, Tomassini Seravalle LR, Manca de Nadra MC, Strasser de Saad AM (2010) Antioxidant capacity and antibacterial activity of phenolic compounds from argentinean herbs infusions. Food Control. 21: 779-785. Link: https://bit.ly/39gxy4x

6. Vallejo CV, Aredes Fernández PA, Farias ME, Rodríguez-Vaquero MJ (2013) Biofilm inhibition of spoilage bacteria by Argentinean fruit juices with antihypertensive activity. Current Pharmaceutical Biotechnology 14: 802-808. Link: https://bit.ly/2wCvw1r

7. Lavoie JL, Sigmund CD (2003) Minireview: overview of the renin-angiotensin system-an endocrine and paracrine system. Endocrinology 144: 2179-2183. Link: https://bit.ly/2QMzr2r

8. Landmesser U, Spiekermann S, Dikalov S, Tatge H, Wilke R, et al. (2002) Vascular oxidative stress and endothelial dysfunction in patients with chronic heart failure: role of xanthine-oxidase and extracellular superoxide dismutase. Circulation 106: 3073-3078. Link: https://bit.ly/39jxCk7

9. Alberto MR, Farías ME, Manca de Nadra MC (2002) Effect of wine phenolic compounds on Lactobacillus hilgardii $5 \mathrm{w}$ viability. J Food Protection 65: 211 213. Link: https://bit.ly/2wtn9Fy 
10. Matias EFF, Santos KK, Almeida TS, Costa JGM, Coutinho HD (2010) In vitro antibacterial activity of Croton campestris A., Ocimum gratissimum L. and Cordia verbenacea DC. Rev Bras Bioci 8: 294-298. Link: https://bit.ly/2xry2HI

11. Gomes TAT, Elias WP, Scaletskya ICA, Gutha BEC, Rodrigues JF, et al. (2016) Diarrheagenic Escherichia coli. Braz J Microbiol 47: 3-30. Link: https://bit.ly/2WLtPtc

12. Gelatti LC, Sukiennik T, Becker AP, Inoue FM, Carmo MS, et al. (2009) Sepsis due to community-acquired methicillin-resistant Staphylococcus aureus in southern Brazil. Rev Soc Bras Med Tro 42: 458-460. Link: https://bit.ly/2xljkSJ

13. Dos Santos FSM, Bezerra JWA, Kamdem JP, Boligon AA, Anraku MM, et al (2019) Polyphenolic composition, antibacterial, modulator and neuroprotective activity of Tarenaya spinosa (Jacq.) Raf. (Cleomaceae). Asian Pac J Trop Biomed 9: 12-17. Link: https://bit.ly/2JevIGR

14. Banks G, John O (2010) Old World, New World, Third World? Reconceptualising the Worlds of Wine. Journal of Wine Research 21: 57-75. Link: https://bit.ly/3dxCu8o

15. Statistical Report on World Vitiviniculture (2019) Statistics Unit of the International Organisation of Vine and Wine (OIV). Link: https://bit.ly/3amThJt

16. Singleton VL, Rossi JA (1965) Colorimetry of total phenolics with phosphomolybdic-Phosphotungstic acid reagents. Am J Enol Viticulture 16 144-158. Link: https://bit.ly/3dsibt3

17. Ghiselli A, Nardini M, Baldi A, Scaccini C (1998) Antioxidant activity of different phenolic fractions separated from an Italian red wine. J Agric Food Chem 46 361-367. Link: https://bit.ly/3bD0JR9

18. Fanzone M, Zamora F, Jofré V, Assof M, Gómez-Cordovés C, et al. (2011) Phenolic characterization of red wines from different grape varieties cultivated in Mendoza province (Argentina). J Sci Food Agric 94: 704-718. Link: https://bit.ly/2xmo8r0

19. Cushman DW, Cheung HS (1971) Spectrophotometric assay and properties of the angiotensin I converting enzyme of rabbit lung. Biochem Pharmacol 20 1637-1648. Link: https://bit.ly/3amtu3Y

20. Hernández-Ledesma B, Martín-Alvarez PJ, Pueyo E (2003) Assesment of the spectrophotometric method for determination of angiotensin converting enzyme activity: influence of the inhibition type. J Agricultural Food Chemistry 51: 4175-4179. Link: https://bit.ly/2QILy0n

21. Benzie IF, Strain JJ (1996) The ferric reducing ability of plasma (FRAP) As measurement of "antioxidant power": The Frap assay. Anal Biochem 239: 70 76. Link: https://bit.ly/3aweFvK

22. Re R, Pellegrini N, Proteggente A, Yang M, Rice-Evans C (1999) Antioxidant activity applying an improved ABTS radical cationdecolorization assay. Free Radic Biol Med 26: 1231-1237. Link: https://bit.ly/2UB8olL

23. Von Gadow A, Joubert E, Hansmann CF (1997) Comparison of antioxidant activity of aspalathin with that of other plant phenols of Rooibosed tea (Aspalathon linearis), a-tocopherol, 278 BHT, and BHA. J Agric Food Chem 45 632-638. Link: https://bit.ly/2Jhiaug

24. Yen GC, Duh PD, Tsai HL (2002) Antioxidant and pro-oxidant properties of ascorbic acid 280 and gallic acid. Food Chemistry 79: 307-313. Link: https://bit.ly/2ya4ejr

25. Clinical and laboratory Standards Institute (2006) Performance Standards for Antimicrobial 282 Susceptibility Testing; Seventeenth Informational Supplement M100 S17 Wayne, USA.

26. Steel RGD, Torrie JH, Dicky DA (1997) Principles and Procedures of Statistics, A 284 Biometrical Approach. 3rd Edition, McGraw Hill, Inc. Book Co., New York, 352-358. Link: https://bit.ly/2xtLSt6
27. Bouarab-Chibane $L$, Forquet $V$, Lantéri $P$, Clément $Y$, Léonard-Akkari $L$, et al. (2019) Antibacterial Properties of Polyphenols: Characterization and QSAR (Quantitative 287 Structure_Activity Relationship) Models. Front Microbiol. 10 829. Link: https://bit.ly/3duD3jw

28. Bezerra JWA, Rodrigues Costa A, Freitas MA (2019) Chemical composition antimicrobial, modulator and antioxidant activity of essential oil of Dysphania ambrosioides (L.) 290 Mosyakin \& Clemants. Comparative Immunology. Microbiology and Infectious Diseases 65: 58-64. Link: https://bit.ly/2WGdje1

29. Fernández-Pachón MS, Villano D, García-Parrilla MC, Troncoso AM (2004) Antioxidant activity of wines and relation with their polyphenolic composition. Analytica Chimica Acta 513: 113-118. Link: https://bit.ly/3amujtA

30. Van-Leeuw R, Kevers C, Pincemail J, Defraigne JO, Dommes J (2014) Antioxidant capacity and phenolic composition of red wines from various grape varieties: Specificity of Pinot Noir. 297 Journal of Food Composition and Analysis 36: 40-50. Link: https://bit.ly/3aioRrW

31. Fidelis M, Sousa Santos J, Bragueto Escher G, Vieira do Carmo M, Azevedon $L$, et al. (2018) In vitro antioxidant and antihypertensive compounds from camu-camu (Myrciaria dubia McVaugh, Myrtaceae) seed coat: A multivariate structure-activity study. Food and Chemical Toxicology 120: 479-490. Link: https://bit.ly/2UDbfRq

32. Putnik P, Granato D (2018) In vitro antioxidant and antihypertensive compounds from camu-300 camu (Myrciaria dubia McVaugh, Myrtaceae) seed coat: A multivariate structureactivity study. 301 Food Chem. Toxicol 120: 479-490. Link: https://bit.ly/2y2t6tc
Discover a bigger Impact and Visibility of your article publication with

\section{Peertechz Publications}

\section{Highlights}

* Signatory publisher of ORCID

* Signatory Publisher of DORA (San Francisco Declaration on Research Assessment)

* Articles archived in worlds' renowned service providers such as Portico, CNKI, AGRIS, TDNet, Base (Bielefeld University Library), CrossRef, Scilit, J-Gate etc.

* Journals indexed in ICMJE, SHERPA/ROMEO, Google Scholar etc.

- OAI-PMH (Open Archives Initiative Protocol for Metadata Harvesting)

* Dedicated Editorial Board for every journal

- Accurate and rapid peer-review process

* Increased citations of published articles through promotions

* Reduced timeline for article publication

Submit your articles and experience a new surge in publication services (https://www.peertechz.com/submission).

Peertechz journals wishes everlasting success in your every endeavours.

Copyright: @ 2020 Rodríguez-Vaquero MJ, et al. This is an open-access article distributed under the terms of the Creative Commons Attribution License, which permits unrestricted use, distribution, and r eproduction in any medium, provided the original author and source are credited.

Citation: Rodríguez-Vaquero MJ, Vallejo CV, Aredes-Fernández PA (2020) Antibacterial, antioxidant and antihypertensive properties of polyphenols from argentinean red wines varieties. Open J Pharmacol Pharmacother 5(1): 001-006. DOI: https://dx.doi.org/10.17352/ojpp.000010 